\title{
Foute en probleme
}

Hierdie keer behandel ek in plaas van reëls uit die $A W S$ weer enkele foute wat dikwels in (skriftelike) Afrikaans voorkom.

\section{1. inteendeel en trouens}

Dit is nogal verbasend hoeveel mense hierdie twee woorde verkeerd gebruik, of liewer: hoeveel mense inteendeel gebruik wanneer hulle trouens bedoel. Niemand sal seker sukkel om te besef dat teendeel 'teenoorgestelde' beteken nie. In regstaal kom 'n mens dit byvoorbeeld teë dat iets vermoed word, sê maar dat iemand 'n misdryf begaan het, "tensy die teendeel bewys word", dit wil sê tensy die vermoede van skuld weerlê word deur bewys van onskuld te lewer.

In die Nederlands van omstreeks die tyd van Jan van Riebeeck was die uitdrukking trouens in 't tegendeel of in het tegendeel, wat in Afrikaans dus in die teendeel is. Hierdie frase of uitdrukking het met verloop van tyd vasgegroei tot integendeel in Nederlands en natuurlik ons inteendeel.

Die vergelykbare uitdrukkings in Engels en Frans is onderskeidelik on the contrary en au contraire.

'n Mens gebruik inteendeel dus om die omgekeerde van, of teenstelling met, dit wat jy pas gesê of geskryf het, te beklemtoon; jy sê juis die teendeel daarvan is die geval, byvoorbeeld:

- $\quad$ Ek het jou nie probeer kul nie; inteendeel, ek het my bes gedoen om jou billik te behandel.

- Ons het verwag om koud te kry, maar dit was inteendeel nogal warm.

- Almal het gedink die taxi het die ongeluk veroorsaak, maar die hof het inteendeel bevind dat hy dit in werklikheid probeer verhoed het.

Daarenteen word trouens gebruik om dit wat pas gesê is, te bekragtig of te bevestig. Dit is dus 'n versterking van wat pas gesê is, byvoorbeeld:

- Dit was nog altyd, en is trouens steeds, verkeerd om jou versekeraar te probeer kul.

- Dit was die afgelope somer nogal warm; trouens, die kraaie het sommer kort-kort gegaap!

- Die drama gebruik kru taal; verfynde taal daarin sou trouens heeltemal onvanpas wees.

\section{2. maar en egter}

Hierdie twee baie algemene woorde waarsku ook van teenstelling of ontkenning ten opsigte van wat pas gesê is. Maar word wel anders as egter in sinne gebruik en het ook meer subtiele betekenisonderskeidings - en dus gebruike - as egter. Maar kan byvoorbeeld gebruik word om twee sinne saam te voeg, terwyl egter meer geredelik ná 'n kommapunt of in 'n volgende sin gebruik word.

Dit is seker nie nodig om voorbeeldsinne van hulle gebruik te gee nie, maar waarteen 'n mens moet waak, is om albei in dieselfde sin te gebruik om dieselfde teenstelling uit te druk. 
Dit is stilisties bedenklik en pleonasties, byvoorbeeld:

- Meganies gesproke is motor X basies dieselfde as motor Y, maar die twee verskil egter hemelsbreed wat stilering betref.

- Ons span is baie goed, maar ons kan dit egter net nie regkry om die oorsese span te klop nie.

In bostaande sinne moet slegs een van die twee gebruik word (met die nodige aanpassings in punktuasie en sinsbou).

In Afrikaans kan 'n mens - met omsigtigheid en inagneming van styloorwegings - 'n sin met maar begin. Daarenteen kan egter, in teenstelling met sy Engelse gelyke however, wat dikwels aan sinsbegin staan, nie in Afrikaans aan sinsbegin staan nie.

\section{3. non-profit in Afrikaans}

'n Mens hoor dikwels van 'n non-profit organisation/company/entity/..., wat m.i. baie dikwels verkeerdelik as "niewinsgewende organisasie/maatskappy/ens." vertaal word. In die Maatskappywet, 2008, kom non-profit companies nogal baie ter sprake.

In Afrikaans sou ons natuurlik "niewinsorganisasie/niewinsmaatskappy" ens. kon sê, en in ons wetgewing is daar 'n enkele geval of twee van "niewinssektor", maar dis eintlik ongewoon.

Die probleem met niewinsgewend as vertaling vir non-profit in hierdie soort konteks is dat'n niewinsgewende entiteit een is wat wins wil of moet maak, maar dit om die een of ander rede nie regkry nie - dus teen 'n verlies werk; die Engels daarvan sou "not profitable" of "nonprofitable" wees. 'n Handelsmaatskappy wat veronderstel is om wins te maak maar bloot gelykbreek of 'n verlies maak, of die sogenaamde semistaatsinstellings (maatskappye in staatsbesit) soos PetroSA of die SAL, wat minstens darem nie 'n las vir die belastingbetaler behoort te wees nie, is dus niewinsgewende maatskappye.

Gewoonlik is 'n non-profit entity een wat glad nie wins ten doel het nie, en daarom is die korrekte vertaling vir non-profit organisation/company/entity/... organisasie/maatskappy/ entiteit/... sonder winsoogmerk. 'n Mens hoor soms ook "sonder winsbejag", wat nie sonder meer verkeerd is nie, maar die -bejag-deel daarvan het meestal'n pejoratiewe waarde en wek die indruk dat die strewe na wins (of eer in eerbejag) oordrewe is en tot elke prys geskied, selfs sonder inagneming van die gevolge.

Entiteite soos welsynsorganisasies is dus organisasies of verenigings (of wat ook al) sonder winsoogmerk, dit wil sê hulle word nie opgerig met die doel om wins te genereer nie, maar om die een of ander maatskaplike, welsyns- of dergelike diens te lewer.

Ek herhaal graag die uitnodiging dat lesers vrae oor praktiese Afrikaanse gebruikskwessies kan instuur, wat ek dan in 'n rubriek sal probeer behandel.

JD (ToM) McLachlan

E-pos: tommcl@whalemail.co.za 